\title{
Trap efficiency evaluation for small mammals in the southern Amazon
}

\author{
Manoel dos SANTOS-FILHO ${ }^{1 *}$, Patrick Ricardo DE LÁZARI ${ }^{1}$, Cícero Pedro Farias de SOUSA², \\ Gustavo Rodrigues CANALE ${ }^{1,3}$ \\ 1 Universidade do Estado de Mato Grosso - UNEMAT, Cidade Universitária, Centro de Pesquisa de Limnologia, Biodiversidade, Etnobiologia do Pantanal, Laboratório de Mastozoologia. \\ Cáceres - Mato Grosso, Brasil. \\ 2 Universidade do Estado de Mato Grosso - UNEMAT. Tangará da Serra - Mato Grosso, Brasil. \\ 3 Universidade Federal do Mato Grosso - UFMT, Núcleo de Estudos da Amazônia Matogrossense - NEBAM. Sinop - Mato Grosso, Brasil. \\ * Corresponding author: msantosfilho@gmail.com
}

\section{ABSTRACT}

The effectiveness of ecological researches on small mammals strongly depends on trapping techniques to survey communities and populations accurately. The main goal of this study was to assess the efficiency of three types of traps (Sherman, Tomahawk and Pitfall) to capture non-volant small mammals. We installed traps in 22 forest fragments in the southern Brazilian Amazonia. We captured 873 individuals belonging to 21 species; most of the individuals $(\mathrm{N}=369)$ and species $(\mathrm{N}=19)$ were trapped using Pitfalls, followed by Shermans ( $\mathrm{N}=271$ individuals; $\mathrm{N}=15$ species $)$ and Tomahawks $(\mathrm{N}=233$ individuals; $\mathrm{N}=15$ species). Pitfalls trapped a richer community subset of small mammals than the two other types of traps, and a more abundant community subset than Tomahawks. Proechimys sp. was the most abundant species trapped $(\mathrm{N}=125)$ and Tomahawk was the most efficient type of trap to capture this species ( $\mathrm{N}=97$ individuals). Neacomys spinosus and Marmosops bishopi were more trapped in Pitfalls ( $=92$ and 100 individuals, respectively) than Shermans and Tomahawks. Monodelphis glirina was more trapped in Shermans and Pitfalls than Tomahawks. Species composition trapped using the three types of traps were distinct. Pitfalls captured a more distinct subset of the small mammal community than the two other live traps. We recommend the association of the three types of traps to reach a more comprehensive sampling of the community of small mammals. Thus, as stated by previous studies, we also recommend the complementary use of Shermans, Tomahawks and Pitfalls to account for a thorough sampling of the whole small mammal community in researches conducted in the tropical forests of Amazonia.

KEYWORDS: Fragments, sampling techniques, abundance, community ecology

\section{Avaliação da eficiência de armadilhas para pequenos mamíferos no sul da Amazônia}

\begin{abstract}
RESUMO
A eficácia das pesquisas ecológicas de comunidade de pequenos mamíferos depende fortemente do uso de técnicas adequadas nas capturas durante as amostragens. O principal objetivos deste estudo foi avaliar a eficiências de três tipos de armadilhas (Sherman, Tomahawk e Pitfall) para capturas de pequenos mamíferos não-voadores. Nós instalamos armadilhas em 22 fragmentos de floresta no sul da Amazonia Brasileira. Nós capturamos 873 indivíduos de 21 espécies, a maior parte dos indivíduos (N=369) e espécies $(\mathrm{N}=19)$ foram capturados usando pitfalls, seguidos de Shermans ( $\mathrm{N}=271$ indivíduos, $\mathrm{N}=15$ espécies) e Tomahawks ( $\mathrm{N}=233$ indivíduos, $\mathrm{N}=15$ espécies). Pitfalls capturou a maior riqueza da comunidade de pequenos mamíferos quando comparada aos outros dois tipos de armadilhas, e uma maior abundancia que Tomahawk. Proechimys sp. foi a espécies mais abundante capturada $(\mathrm{N}=125)$ e Tomahawk foi o tipo de armadilha mais eficiente para a captura desta espécie ( $\mathrm{N}=97$ indivíduos). Neacomys spinosus e Marmosops bishopi foram mais capturados em Pitfalls ( $\mathrm{N}=92$ e 100 indivíduos, respectivamente) que Shermans e Tomahawks. Monodelphis glirina foram mais capturados em Shermans e Pitfalls que Tomahawks. A composição de espécies capturada usando os três tipos de armadilhas foi distinta. Pitfalls capturou um diferente subgrupo da comunidade de pequenos mamíferos quando comparado aos outros dois tipos de live traps. Assim, como sugerido em estudos anteriores, nós também recomendamos o uso conjugado de Sherman, Tomahawks e Pitfalls para uma amostragem mais completa da comunidade de pequenos mamíferos em pesquisas realizadas nas florestas tropicais da Amazônia.
\end{abstract}

PALAVRAS-CHAVE: Fragmentos, técnica de amostragens, abundância, ecologia de comunidade 


\section{INTRODUCTION}

Most ecological studies on small mammals involve trapping of individuals for distinct purposes, such as population surveys, assessment of community structure, behavioural studies and population genetics. The success of these studies must rely on adequate trapping techniques that will evenly sample individuals (populations and/or communities) to avoid biased results and to lead to sound conclusions (Nicolas and Colyn 2006).

Neotropical mammals are represented by animals with a vast array of body sizes and biological traits, of the 700 species in Brazil (Paglia et al. 2012), 44\% are small mammals weighing no more than one kilogram (Emmons and Feer 1997). Researchers need a variety of trapping techniques to sample small mammal communities with such a large diversity of species, varying ecological requirements and a broad behavioural repertoire (Voss and Emmons 1996; Woodman et al. 1996; Hice and Schmidly 2002).

Richness and abundance of small mammals are more accurately estimated when using more than one type of trap, such as Shermans, Tomahawks, youngs and snap traps (Voss et al. 2001; Pardini 2004; Santos-Filho et al. 2012). Previous studies showed that Pitfall traps are more effective than conventional traps (Nicolas and Colyn 2006; Umetsu et al. 2006), however Pitfalls are rarely used for sampling small mammals in tropical forests.

The main goal of this study was to assess the efficiency of three types of traps (Sherman, Tomahawk and Pitfall) to capture non-volant small mammals in the southern Amazon. Trap efficiency was based on abundance, richness and species composition of the small mammal community subset captured in each one of the three types of trap.

\section{MATERIALS AND METHODS}

\section{Study site}

The research was conducted in the municipality of Alta Floresta in the State of Mato Grosso in the southern Amazonia $\left(09^{\circ} 53 \mathrm{~S}, 56^{\circ} 28 \mathrm{~W}\right)$, with a mean annual rainfall between 2500 $-2700 \mathrm{~mm}$ (Oliveira and Albuquerque 2003). Deforestation in the study site began in the early 1980s and in 2004 only $32 \%$ of the original forest remained in a highly-fragmented landscape (Michalski et al. 2007). Twenty-one forest fragments ranging from two to 14,480 ha were selected to as sites for this research. All were surrounded by pasture and with few emergent trees due to intense selective logging in the past.

\section{Sampling methods}

Forest fragments were sampled for 10 consecutive days from April to August 2009. We used two widely used types of live-trap (Tomahawk and Sherman) and Pitfall traps to sample small mammals with different substrate preferences: arboreal, terrestrial or scansorial. Using three types of traps we expected to sample most of the local small mammal community (Woodman et al. 1996; Voss et al. 2001; Hice and Schmidly 2002).

One ground-level grid of traps was installed in forest fragments ranging from one to 25 ha, two ground-level grids were installed 200 meters apart in forest fragments between $26 \mathrm{ha}$ and $100 \mathrm{ha}$, and three ground-level grids were installed in forest fragments larger than 100 ha. Each ground-level grid was consisted of three parallel transects, each transect was 100 meters long and separated by $50 \mathrm{~m}$ from the next. A trapping point was established every 20 meters along each transect, totalling five trapping points on each of the three transects. One Sherman $(80 \mathrm{~mm} \times 90 \mathrm{~mm} \times 230 \mathrm{~mm})$ and one Tomahawk ( $145 \mathrm{~mm} \times 145 \mathrm{~mm} \times 410 \mathrm{~mm})$ were installed on the ground, three meters apart from each other, at each trapping point, totalling 30 live traps at each ground-level grid. Traps were baited with peanut-butter and three slices of banana and were checked daily to collect trapped small mammals and replace baits.

A Pitfall set of four plastic buckets (60 l) was installed in "Y" shape. Buckets were buried fifteen meters one from the other. A plastic canvas of 70 centimeters in height was used as a barrier linking the rims of all four buckets. One Pitfall set was installed in forest fragments ranging from two to 25 ha, and four Pitfall sets were installed 200 metres apart in forest fragments larger than 50 ha. A styrofoam plate was placed inside each bucket to prevent drowning of any captured animals. Buckets remained open for 10 consecutive days and were checked daily to collect small mammals and remove any rainwater.

Voucher specimens of each species were deposited at the Mammal Collections of the Universidade do Estado de Mato Grosso (UNEMAT), Cáceres. Since none of the fragments yielded more than 20 individuals per species, all individuals in this study were collected, rendering a mark-recapture approach unnecessary.

\section{Statistical analyses}

Abundance was weighed by the total number of trapnights for each one of the three types of traps. Weighed abundance was log-transformed to avoid dominance of overabundant species in the determination of the similarity matrix. We used analysis of similarity (ANOSIM) and non-metric multidimensional scaling (NMDS) to evaluate similarities in species composition of the small mammals trapped by the three types of traps. The non-parametric Wilcoxon's rank test was used to compare weighed abundance of small mammals trapped in the three types of traps. We also used Wilcoxon's rank test to compare weighed abundance of the most abundant small mammals trapped in each of the three types of traps. Due to the performance of multiple paired comparisons we 
used simple Bonferroni correction to compensate for error inflation. Statistical significance was set at P $(\leq) 0.016$ after Bonferroni correction. Statistical analyses were performed in R program (R Core Team 2012).

Species rarefaction curves based on the number of species and the number of fragments (Gotelli and Colwell 2001) were used to examine our sampling sufficiency using the EstimateS software (Colwell 1997), on the basis of the Sobs Mao Tau index.

\section{RESULTS}

We captured 873 individuals from 21 species of small mammals (Table 1). Nineteen species and 369 individuals were captured in Pitfalls with 2,880 trap.nights, 15 species and 271 individuals in Shermans with 6,300 trap.nights, and 15 species and 233 individuals in Tomahawks with 6,300 trap.nights. The capture success was $12.8 \%$ in Pitfalls, $4.3 \%$ in Shermans and $3.6 \%$ in Tomahawks.

Table 1. Species captured using three types of traps in the southern Amazon in the municipality of Alta Floresta, Mato Gosso. (Ter= cursorial or terrestrial species, Arb = arboreal or scansorial species) $(\mathrm{N}=21$ forest fragments).

\begin{tabular}{|c|c|c|c|c|c|c|c|c|}
\hline \multirow{2}{*}{ Species } & \multirow{2}{*}{$\begin{array}{c}\text { Habitat } \\
\text { Use }\end{array}$} & \multicolumn{2}{|c|}{ Tomahawk } & \multicolumn{2}{|c|}{ Sherman } & \multicolumn{2}{|r|}{ Pitfall } & \multirow{2}{*}{$\begin{array}{r}\text { All traps } \\
\text { Total }\end{array}$} \\
\hline & & Total & Mean $\pm S D$ & Total & Mean $\pm S D$ & Total & Mean $\pm S D$ & \\
\hline Proechimys sp. (Allen, 1899) & Ter & 97 & $4.62 \pm 3.61$ & 22 & $1.05 \pm 1.43$ & 6 & $0.28 \pm 0.78$ & 125 \\
\hline Marmosa demerarae (Thomas, 1905) & Arb & 61 & $2.90 \pm 3.45$ & 59 & $2.81 \pm 2.84$ & 4 & $0.19 \pm 0.40$ & 124 \\
\hline Neacomys spinosus (Thomas, 1882) & Ter & 4 & $0.19 \pm 0.51$ & 26 & $1.24 \pm 2.21$ & 92 & $4.38 \pm 5.11$ & 122 \\
\hline Necromys lasiurus (Lund, 1840) & Ter & 0 & - & 2 & $0.90 \pm 0.30$ & 21 & $1.00 \pm 1.45$ & 23 \\
\hline Marmosops bishop (Pine, 1981) & Arb & 1 & $0.05 \pm 0.22$ & 3 & $0.14 \pm 0.36$ & 100 & $4.76 \pm 5.27$ & 104 \\
\hline Monodelphis glirina (Wagner, 1842) & Ter & 11 & $0.52 \pm 0.93$ & 51 & $2.43 \pm 3.07$ & 36 & $1.71 \pm 2.10$ & 98 \\
\hline Euryoryzomys nitidus (Thomas, 1884) & Ter & 11 & $0.52 \pm 0.75$ & 39 & $1.86 \pm 2.76$ & 5 & $0.24 \pm 0.54$ & 55 \\
\hline Hylaeamys megacephalus (Fischer, 1814) & Ter & 13 & $0.62 \pm 1.57$ & 29 & $1.38 \pm 2.52$ & 12 & $0.57 \pm 1.03$ & 54 \\
\hline Marmosa murina (Linnaeus, 1758) & Arb & 5 & $0.24 \pm 0.54$ & 14 & $0.66 \pm 1.74$ & 20 & $0.95 \pm 1.46$ & 39 \\
\hline Monodelphis adusta (Thomas, 1897) & Ter & 0 & - & 2 & $0.09 \pm 0.44$ & 34 & $1.62 \pm 2.92$ & 36 \\
\hline Oligoryzomys sp. (Bangs, 1900) & Ter & 0 & - & 5 & $0.24 \pm 0.62$ & 12 & $0.57 \pm 0.92$ & 17 \\
\hline Didelphis marsupialis (Linnaeus, 1758) & Arb & 16 & $0.76 \pm 1.09$ & 0 & - & 2 & $0.90 \pm 0.30$ & 18 \\
\hline Oecomys sp. (Thomas, 1906) & Arb & 1 & $0.05 \pm 0.22$ & 5 & $0.24 \pm 0.54$ & 11 & $0.52 \pm 0.93$ & 17 \\
\hline Oecomys bicolor (Tomes, 1860) & Arb & 1 & $0.05 \pm 0.22$ & 10 & $0.48 \pm 0.75$ & 3 & $0.14 \pm 0.48$ & 14 \\
\hline Oecomys roberti (Thomas, 1903) & Arb & 4 & $0.19 \pm 0.40$ & 3 & $0.14 \pm 0.48$ & 2 & $0.90 \pm 0.30$ & 9 \\
\hline Oecomys aff. catherinae (Thomas, 1909) & Arb & 2 & $0.90 \pm 0.30$ & 0 & - & 5 & $0.24 \pm 0.70$ & 7 \\
\hline Metachirus nudicaudatus (É. Geoffroy, 1803) & Ter & 5 & $0.24 \pm 0.54$ & 1 & $0.05 \pm 0.22$ & 0 & - & 6 \\
\hline Oxymycterus sp. (Waterhouse, 1837) & Ter & 0 & - & 0 & - & 2 & $0.90 \pm 0.30$ & 2 \\
\hline Caluromys lanatus (Olfers, 1818) & Arb & 1 & $0.05 \pm 0.22$ & 0 & - & 0 & - & 1 \\
\hline Glacilinanus sp. (Gardner and Creighton, 1989) & Arb & 0 & - & 0 & - & 1 & $0.05 \pm 0.22$ & 1 \\
\hline Marmosa sp. (Gray, 1821) & Arb & 0 & - & 0 & - & 1 & $0.05 \pm 0.22$ & 1 \\
\hline Species richness & & 15 & & 15 & & 19 & & 21 \\
\hline Individuals captured & & 233 & & 271 & & 369 & & 873 \\
\hline
\end{tabular}


When comparing abundance of small mammals trapped using the three types of traps, more individuals were trapped using Pitfalls than Tomahawks (W $\left.=8, \mathrm{P}_{\text {(Bonferroni) }}=0.013\right)$, no other comparison was statistically relevant $(\mathrm{W}=46-22.5$, $\mathrm{P}_{\text {(Bonferroni) }} \geq 0.016$ ).

For species richness, when the three types of traps were compared, Pitfalls and Shermans show an asymptotic curve after the $15^{\text {th }}$ forest fragment. In addition there was a reduction in the confidence interval for Pitfalls (Figure 1). Comparing trap efficiency for species most commonly trapped during the
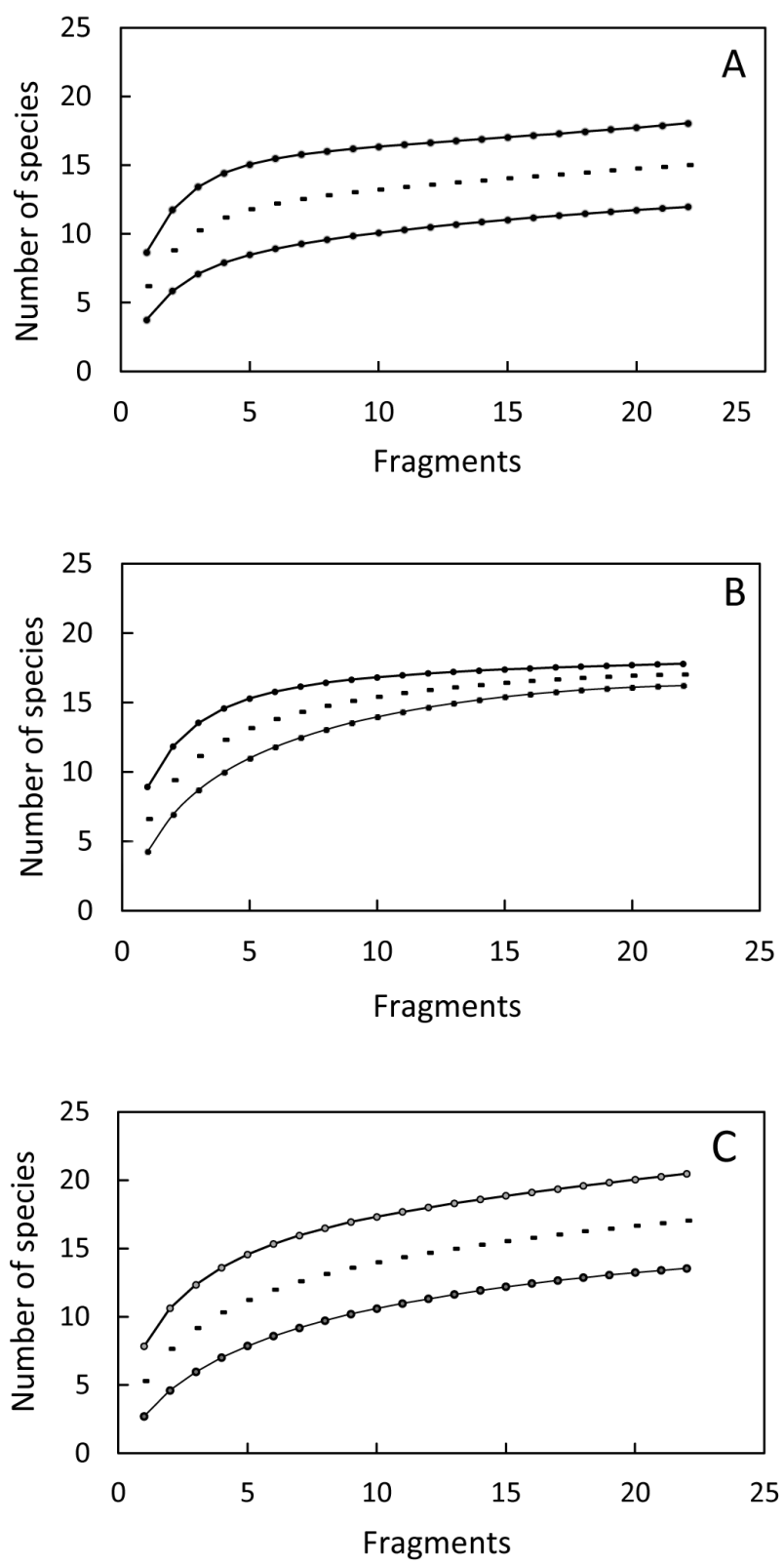

Figure 1. Rarefaction curve of species richness trapped in 22 forest fragments. $A=$ Sherman, $B=$ Pitfalls e $C=$ Tomahawk research (species with more than 90 individuals captured in total) (Figure 2): Neacomys spinosus was more often captured in Pitfalls $(\mathrm{N}=92)$ than in Shermans $(\mathrm{N}=26)(\mathrm{W}=113.5$, $\left.\mathrm{P}_{\text {(Bonferroni) }}=0.004\right)$ or Tomahawks $(\mathrm{N}=4)\left(\mathrm{W}=357, \mathrm{P}_{\text {(Bonferroni) }}\right.$ $=0.0001)$. Proechimys sp. was more commonly trapped in Tomahawks $(\mathrm{N}=97)$ than in Shermans $(\mathrm{N}=22)(\mathrm{W}=71.5$, $\left.\mathrm{P}_{\text {(Bonferroni) }}=0.0001\right)$ or Pitfalls $(\mathrm{N}=6)\left(\mathrm{W}=52, \mathrm{P}_{\text {(Bonferroni) }}=\right.$ 0.0001). While, Monodelphis glirina was more often captured in Shermans $(\mathrm{N}=51)$ than Tomahawks $(\mathrm{N}=11)(\mathrm{W}=318.5$, $\left.P_{\text {(Bonferroni) }}=0.009\right)$, there was no difference between number of individuals captured in Pitfalls $(\mathrm{N}=36)$ and in the two other types of traps. Marmosops bishopi was most commonly trapped in Pitfalls $(\mathrm{N}=100)$ than in Shermans $(\mathrm{N}=3)$ $\left(\mathrm{W}=0, \mathrm{P}_{\text {(Bonferroni) }}=0.0001\right)$ or Tomahawks $(\mathrm{N}=1)(\mathrm{W}=$ $\left.0, \mathrm{P}_{\text {(Bonferroni) }}=0.0001\right)$, moreover Shermans captured more individuals than Tomahawks ( $\left.\mathrm{W}=294.5, \mathrm{P}_{\text {(Bonferroni) }}=0.009\right)$. On the other hand, Marmosa demerarae was less frequently trapped in Pitfalls $(\mathrm{N}=4)$ than in Tomahawks $(\mathrm{N}=61)(\mathrm{W}$ $\left.=86.5, \mathrm{P}_{(\text {Bonferroni) }}=0.0003\right)$ or Shermans $(\mathrm{N}=59)(\mathrm{W}=359$, $\left.\mathrm{P}_{\text {(Bonferroni) }}=0.0002\right)$.

The ANOSIM and NMDS results revealed a significant difference in the community composition sampled by different types of traps. The species trapped using Pitfall traps were different than those using Tomahawks or Shermans (respectively, $\mathrm{R}=0.78$ and $0.57, \mathrm{P}<0.001$; Figure $3 \mathrm{~A}$ ), there was a smaller difference between the two latter $(\mathrm{R}=0.25, \mathrm{P}<0.001$; Figure $3 \mathrm{~A})$. The same pattern was observed when only presence - absence data was used (Pitfall/Tomahawk: $\mathrm{R}=0.70$; Pitfall/Sherman: $\mathrm{R}=0.47$; Sherman/Tomahawk $\mathrm{R}=0.17 ; \mathrm{P}<0.001$; Figure 3B).

\section{DISCUSSION}

Pitfalls were more efficient than Shermans and Tomahawks, trapping more species of small mammals and sampling a more distinct subset (Bury and Corn 1987; Lyra-Jorge and Pirvello 2001 and Umetsu et al. 2006). Additionally, Pitfalls trapped a higher number of individuals than Tomahawks, but there was no significant difference in the number of individuals trapped by Pitfalls and Shermans. A similar pattern has been observed in African tropical forests (Nicolas and Colin 2006), in Brazilian Cerrado (Cáceres et al. 2011) and at the Atlantic Forest (Umetsu et al. 2006) where Pitfalls were more efficient than Shermans and/or Tomahawks, capturing a higher number of species and individuals. We demonstrate, however, that different types of traps have distinct efficiency depending on the small mammal species targeted.

When analysing trap efficiency based on abundance of small mammals trapped for the whole small mammal community, Pitfalls were a more efficient type of trap than Tomahawks, but not for all species of the community. The four largest species of small mammals captured, Caluromys lanatus, Metachirus nudicaudatus, Didelphis marsupialis and 


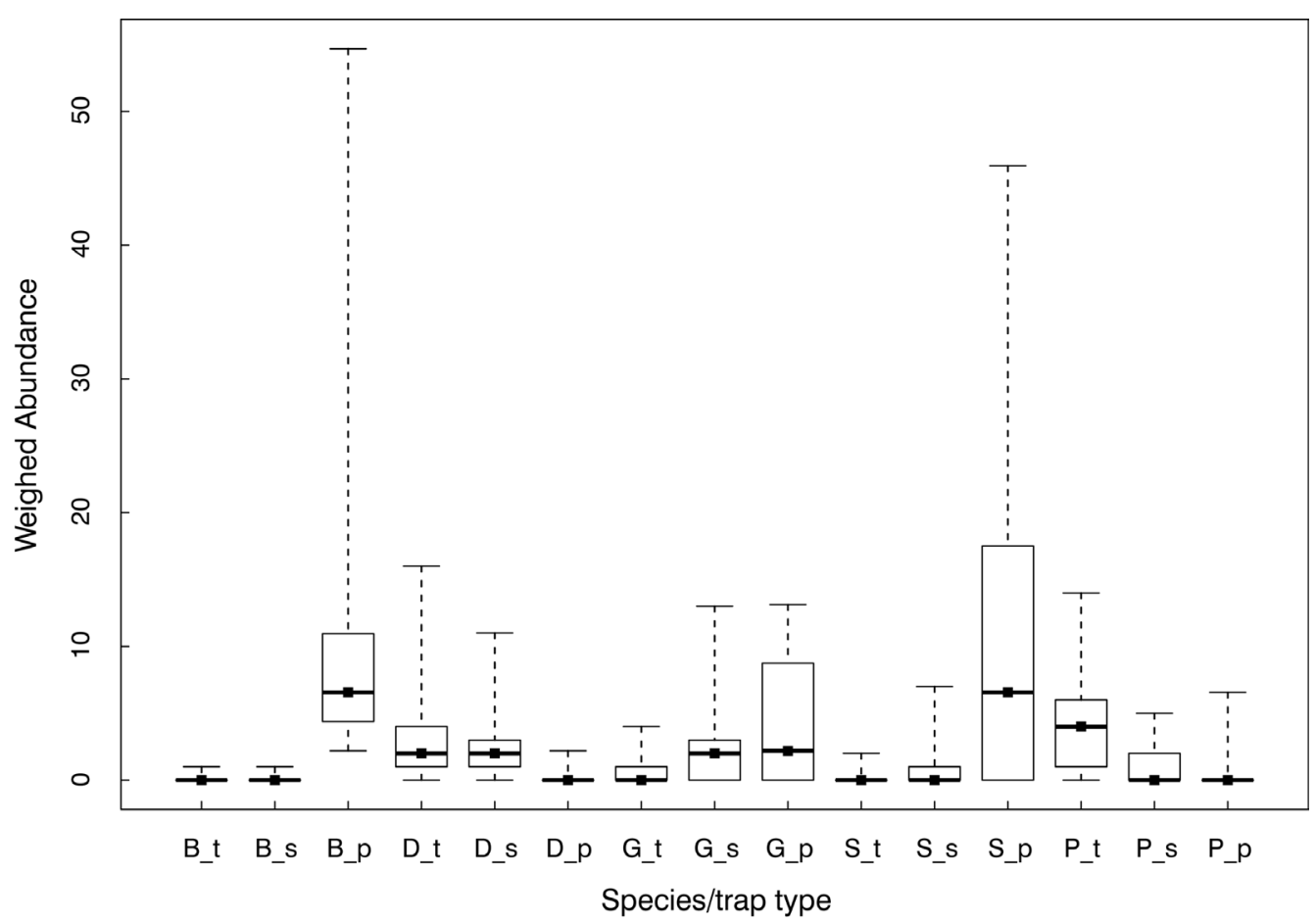

Figure 2. Weigh abundance of five of the most abundant species captured in the southern Amazonia, municipality of Alta Floresta, State of Mato Grosso, Brazil. Dark squares show medians and whiskers show maximum and minimum weighed abundance recorded. $\mathrm{B}=$ Marmosops bishopi, $\mathrm{D}=$ Didelphis marsupialis, $\mathrm{G}=$ Monodelphis glirina, $\mathrm{S}=$ Neacomys spinosus, $\mathrm{P}=$ Proechimys $\mathrm{sp} . \_\mathrm{t}=$ Tomahawks, $\mathrm{S}=$ Shermans, $\_\mathrm{p}=$ Pitfalls.
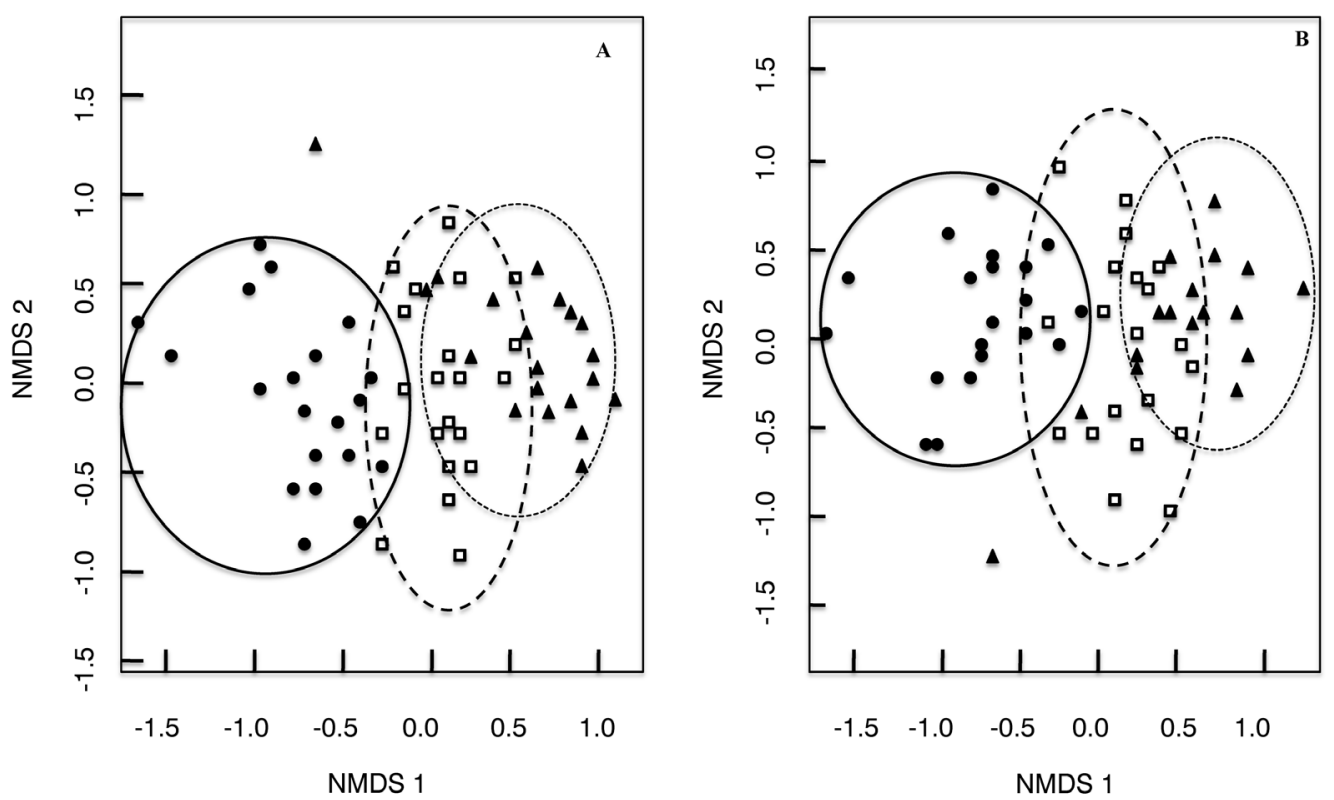

Figure 3. Two-dimensional NMDS plots of the similarity among community structure using three types of traps. Black dots circled by a black line: captures using Pitfalls, white squares circled by a dashed line = captures using Shermans, and black triangles circled by points = captures using Tomahawks. (A) NMDS using abundance data (B) NMDS using presence-absence data. 
Proechimys sp, had more individuals trapped in Tomahawks than in Pitfalls and Shermans, similar to findings at the Peruvian Amazon (Hice and Velazco 2013). Shermans must be too small to trap adult individuals of these species, and Pitfalls may allow individuals to escape by jumping and climbing.

Although less Pitfall traps (buckets) were used than Shermans and Tomahawks, Pitfalls captured more individuals than the two because they capture more than one individual at the same time, including cursorial, semi-fossorial and arboreal species (Lyra-Jorge and Pirvello 2001; Santos-Filho et al. 2006). Some rare and elusive species, rarely captured with conventional traps, are commonly trapped with Pitfalls (Umetsu et al. 2006; Cáceres et al. 2011).

For arboreal mammals captured in the three types of traps, the only significant difference was observed for Marmosops bishopi, with the highest number of individuals trapped in Pitfalls, and for Marmosa demerarae with less individuals in Pitfalls than in the two other types. In addition, five other arboreal species, (Glacilinanus sp, Marmosa sp., M. murina, Oecomys sp, $O$. aff. catherinae) had more individuals trapped in Pitfalls than in Shermans or Tomahawks.

The main advantage of using Pitfalls is the possibility of collecting more than one individual per trap-night and also to spare the use of baits. To enhance the trap efficiency of Pitfalls we recommend the use of 60-litre buckets or larger, as the use of smaller buckets may allow small mammals to escape, especially those able to jump and climb, such as Proechimys, Didelphis, Caluromys and Oecomys (Santos-Filho et al. 2006; Ribeiro-Júnior et al. 2011).

\section{CONCLUSION}

A richer community subset was captured with Pitfalls than with Tomahawks or Shermans, and more individuals were trapped with Pitfalls than with Tomahawks. Finally, Pitfalls captured a more distinct subset of the small mammal community than the two other live traps. The exclusive use of conventional types of traps (Shermans and Tomahawks) to sample small mammals may generate misleading results even for some arboreal small mammals. Although previous studies had already highlighted the importance of using Pitfalls and conventional traps, this is the first study to compare trap efficiency of Tomahawks, Shermans and Pitfall for trapping small mammals in the Amazon, considering three diversity aspects - richness, abundance and species composition. Similar findings was only recorded for Neotropical small mammals in the Cerrado and in the Atlantic Forest, in accordance to previous studies we recommend the complementary use of Shermans, Tomahawks and Pitfalls to give the most complete sampling of the small mammal community in researches conducted in the tropical forests of Amazonia.

\section{ACKNOWLEDGEMENTS}

We acknowledge the Escola da Amazônia for logistic support during data collection. We also thank Vitória da Riva Carvalho for lodging in Hotel Floresta Amazônica and all landowners for permission to work within their landholdings.

\section{REFERENCES}

Bury, R.B.; Corn, P.S. 1987. Evaluation of Pitfall trapping in northwestern forests: trap array with drift fences. Journal of Wildlife Management, 51: 112-119.

Caceres, N. C.; Nápoli, R. P.; Hannibal, W. 2011. Differential trapping success for small mammals using pitfall and standard cage traps in a woodland savannah region of southwestern Brazil. Mammalia, 75: 45-52.

Colwell, R.K. 1997. Programa EstimateS, version 5: Statistical estimation of species richness and shared species from samples. User's Guide and application published at: http://viceroy.eeb. uconn.edu/estimates.

Emmons, L.H.; Feer, F. 1997. Neotropical rainforest mammals: a field guide. 2da ed. University of Chicago Press, Chicago, 1997, 307p.

Gotelli, N.J.; Colwell, R.K. 2001. Quantifying biodiversity: procedures and pitfalls in the measurement and comparison of species richness. Ecology Letter, 4:379-391.

Hice, C.L.; Schmidly, D.J. 2002. The effectiveness of Pitfall traps for sampling small mammals in the Amazon Basin. Mastozoologia Neotropical, 9: 85-89.

Hice, C.L.; Velazco, P.M. 2013. Relative effectiveness of several bait and trap types for assessing terrestrial small mammal communities in Neotropical rainforest. Occasional Papers Museum of Texas Tech University, 316:1-15.

Lyra-Jorge, M. C.; Pivello, V.R. 2001. Combining live trap and pitfall to survey terrestrial small mammals in savanna and forest habitats, in Brazil. Mammalia, 65:524-530.

Michalski, F.; Nishi, I.; Peres, C.A. 2007. Disturbance-mediated drift in tree functional groups in Amazonian forest fragments. Biotropica, 39: 691-701.

Nicolas, V.; Colyn, M. 2006. Relative efficiency of three types of small mammal traps in an African rainforest. Belgian Journal of Zoology, 136: 107-111.

Oliveira, C.C.; Albuquerque, M.C. 2003. Geologia e recursos minerais da folha de Alta Floresta. Brasília CPRM - Serviço Geológico do Brasil/ DEPAT/ DIEDIG.

Paglia, A.P.; Fonseca, G.A.B.; Rylands, A.B.; Herrmann, G.; Aguiar, L.M.S.; Chiarello, A.G.; et al. 2012. Lista anotada dos mamíferos do Brasil. 2da ed. Occasional Papers in Conservation Biology, 6: 1-76.

Pardini, R. 2004. Effects of forest fragmentation on small mammals in an Atlantic Forest landscape. Biodiversity and Conservation, 13: 2567-2586.

R Core Team. 2012. R: A language and environment for statistical computing. R Foundation for Statistical Computing, Vienna, Austria. http://www.R-project.org/ 
Ribeiro-Júnior, M.A.; Rossi, R.V.; Miranda, C.L.; Ávila-Pires, T.C.S. 2011. Influence of pitfall trap size and design on herpetofauna and small mammal studies in a Neotropical Forest. Zoologia, 28: 80-91.

Santos-Filho, M.; Peres, C.A; Silva, D.J.; Sanaiotti, T.M. 2012. Habitat patch and matrix effects on small-mammal persistence in Amazonian forest fragments. Biodiversity and Conservation, 21: 1127-1147.

Santos-Filho, M.; Silva, D.J.; Sanaiotti, T.M. 2006. Efficiency of four trap types in sampling small mammals in forest fragments, Mato Grosso, Brazil. Mastozoología Neotropical, 13: 217-225.

Umetsu, F.; Naxara, L.; Pardini, R. 2006. Evaluating the efficiency of pitfall traps for sampling small mammals in the Neotropics. Journal of Mammalogy, 87: 757-765.
Voss, R.S.; Emmons, L.H. 1996. Mammalian diversity in Neotropical lowland rainforests: a preliminary assessment. Bulletin of the American Museum of Natural History. New York, 230, 115p.

Voss, R.S.; Lunde, D.P.; Simmons, N.B. 2001. The Mammals of Paracou, French Guiana: a neotropical lowland rainforest fauna part 2. nonvolant species. Bulletin of the American Museun of Natural History. New York, 263, 236 p.

Woodman, N.; Timm, R.M.; Slade, N.A.; Doonan, T.J. 1996. Comparison of traps and baits for censusing small mammals in neotropical lowlands. Journal of Mammalogy, 77: 274-281.

Recebido em 14/05/2014

Aceito em 16/09/2014 
